\title{
Back to Methuselah: I
}

\author{
CHARLES RICKETTS
}

From Charles Ricketts, Self-Portrait taken from the Letters and Journals of Charles Ricketts, $R A$, collected and compiled by T. Sturge Moore, ed. Cecil Lewis (London: Peter Davies, 1939) pp. 294-5. Charles Ricketts (1866-1931), designer, painter, sculptor and author, designed sets and costumes for Shaw plays in the early 1920s. The meeting he describes here took place on 8 May 1918. Shaw had begun writing Back to Methuselah, the work referred to in the conversation, in March of that year. Mrs Lee Mathews was an accomplished pianist and musician who held 'charming chamber concerts' at her home in London in the early decades of the twentieth century (see Ricketts, Self-Portrait, p. 175).

Shaw met me on the stairs as I was leaving the music-room at Mrs Lee Mathews'. He said, 'Tell me, is the war inspiring you? Are you doing big things?' 'No, my dear chap, it is a nightmare, a bore. I view it as I would an earthquake.' 'I am like you - at least, any attempt of mine has been disastrous.' I said, 'But in your case it might not have been so, your work is in touch with reality, mine as a painter is in a backwater; for years I have absorbed only what interested me, or was needful to my work. Were I young, I might respond to events, but I am too old by this time; if I did, it would be too late, life is too short.' 'Curious,' said Shaw, 'I am at work on that subject - the shortness of life. I deal with the future, the secret of longevity has been discovered, men have time for adventure, discovery and work. There are very funny things: my hero, or one of them, is a survivor in the Colonies from our times; he hates all he sees, yet people are kind to him, he is given a home as he is unable to fend for himself; he takes up a sheet of notepaper to write to his wife, and discovers from it he is in a madhouse.' We were descending the stairs. I said, 'Life is too short, I wonder if time slows down later?' Shaw said, 'Yes, I think it does. I am sixty-three, and I feel from time to time that bland sensation one experiences in autumn afternoons - one becomes a spectator as one was in childhood.' 